\title{
WST11, A Novel Water-soluble Bacteriochlorophyll Derivative; Cellular Uptake, Pharmacokinetics, Biodistribution and Vascular-targeted Photodynamic Activity Using Melanoma Tumors as a Model
}

\author{
Ohad Mazor ${ }^{1,2}$, Alexander Brandis ${ }^{2}$, Vicki Plaks ${ }^{1}$, Eran Neumark', Varda Rosenbach-Belkin ${ }^{2}$, \\ Yoram Salomon ${ }^{1}$ and Avigdor Scherz ${ }^{* 2}$ \\ ${ }^{1}$ Department of Biological Regulation, The Weizmann Institute of Science, Rehovot, Israel \\ ${ }^{2}$ Department of Plant Sciences, The Weizmann Institute of Science, Rehovot, Israel
}

Received 14 June 2004; accepted 17 December 2004

\begin{abstract}
WST11 is a novel negatively charged water-soluble palladiumbacteriochlorophyll derivative that was developed for vascular-targeted photodynamic therapy (VTP) in our laboratory. The in vitro results suggest that WST11 cellular uptake, clearance and phototoxicity are mediated by serum albumin trafficking. In vivo, WST11 was found to clear rapidly from the circulation $\left(t_{1 / 2}=1.65 \mathrm{~min}\right)$ after intravenous bolus injection in the mouse, whereas a longer clearance time $\left(t_{1 / 2}=7.5 \mathrm{~min}\right)$ was noted in rats after $20 \mathrm{~min}$ of infusion. The biodistribution of WST11 in mouse tissues indicates hepatic clearance $\left(t_{1 / 2}=20\right.$ min), with minor (kidney, lung and spleen) or no intermediary accumulation in other tissues. As soon as $1 \mathrm{~h}$ after injection, WST11 had nearly cleared from the body of the mouse, except for a temporal accumulation in the lungs from which it cleared within $40 \mathrm{~min}$. On the basis of these results, we set the VTP protocol for a short illumination period $(5 \mathrm{~min})$, delivered immediately after WST11 injection. On subjecting M2R melanoma xenografts to WST11-VTP, we achieved $100 \%$ tumor flattening at all doses and a $70 \%$ cure with $9 \mathrm{mg} / \mathrm{kg}$ and a light exposure dose of $100 \mathrm{~mW} / \mathrm{cm}^{2}$. These results provide direct evidence that WST11 is an effective agent for VTP and provide guidelines for further development of new candidates.
\end{abstract}

\section{INTRODUCTION}

Photodynamic therapy (PDT) is a relatively new modality for treatment of solid tumors, which is based on administering a photosensitive agent followed by its in situ excitation at a matching wavelength. Through photogeneration of reactive oxygen species

\Posted on the website on 28 December 2004

*To whom correspondence should be addressed: Department of Plant Sciences, Weizmann Institute of Science, Herzel Street, Rehovot 76100 , Israel. Fax: 972-8-9344181; e-mail: avigdor.scherz@weizmann.ac.il

Abbreviations: AVT, antivascular chemotherapy; Bchl, bacteriochlorophyll; BSA, bovine serum albumin; DDW, double-distilled water; FCS, fetal calf serum; ICP-MS, inductively coupled plasma mass spectroscopy; i.p., intraperitoneal; i.v., intravenous; PBS, phosphate-buffered saline; Pd-Bpheid, palladium-bacteriopheophorbide; PDT, photodynamic therapy; ROS, reactive oxygen species; SA, serum albumin; VTP, vascular-targeted photodynamic therapy.

(C) 2005 American Society for Photobiology 0031-8655/05
(ROS) at cytotoxic levels, PDT induces a series of destructive processes leading to irreversible cell or tissue damage followed by regression of early and advanced stage tumors (1-4).

The spectra, photophysics and photochemistry of native bacteriochlorophylls (Bchl) make them very efficient sensitizers, possessing optimal light-harvesting properties and with clear advantages as sensitizers in PDT (5). In particular, these molecules have a very high extinction coefficient at long wavelengths $\left(\lambda_{\max }=760-780 \mathrm{~nm}\right.$, $\left.\varepsilon=(4-10) \times 10^{4} M^{-1} \mathrm{~cm}^{-1}\right)$ where light penetrates deeply into tissues, and they generate ROS at a high quantum yield (depending on the central metal and, to some extent, on peripheral substituting groups) $(6,7)$.

Several second-generation sensitizers were derived from Bchl $a$ in our laboratories at the Weizmann Institute (8-10) and further developed as PDT agents for clinical applications in collaboration with Steba-Biotech (Paris, France) and Negma-Lerads (ToussusLe-Noble, France). Substitution of the central magnesium atom of Bchl for palladium and hydrolysis of the esterifying alcohol provided a highly stable and efficient sensitizer, palladiumbacteriopheophorbide (Pd-Bpheid, also known as Tookad ${ }^{\circledR}$ or WST09 (8, A. Scherz and coworkers, personal communication). This novel sensitizer was shown to be effective in the PDT of several solid tumors such as melanoma (11), rat glioma (12), human prostate xenografts $(13,14)$, human HT29 colon carcinoma xenografts (15), normal canine prostate (16) and DS Sarcoma $(17,18)$ in laboratory animal models. After bolus intravenous (i.v.) administration, $95 \%$ of the Tookad ${ }^{\circledR}$ clears from the circulation with a very short half lifetime $\left(t_{1 / 2}=0.6 \mathrm{~min}\right.$, after bolus injection) (19) and the rest with $t_{1 / 2} \sim 11$ min (A. Brandis, O. Mazor, S. Gross, N. Koudinova, E. Gladysh, R. Hami, N. Kammhuber, V. Rosenbach-Belkin, M. Greenwald, A. Bondon, G. Simonneaux, H. Scheer, Y. Salomon and A. Scherz, personal communication,19) with little or no extravasation into the surrounding tissues. After Tookad ${ }^{\circledR}$ perfusion, the majority of the drug clears from the circulation $\mathrm{t}_{1 / 2} \sim 8 \mathrm{~min}$. These properties are appropriate for vascular-targeted photodynamic therapy (VTP). In these studies, illumination is applied when the concentration of the drug in the circulation is sufficiently high. Under these conditions, ROS are photogenerated at high concentrations only within the blood vessels of the illuminated tissue. Oxygen depletion and ROS generation initiate blood stasis as well as rapid destruction of the blood vessels of the tumor, leading to hypoxia and secondary radical formation that culminates in necrosis and eradication of the 

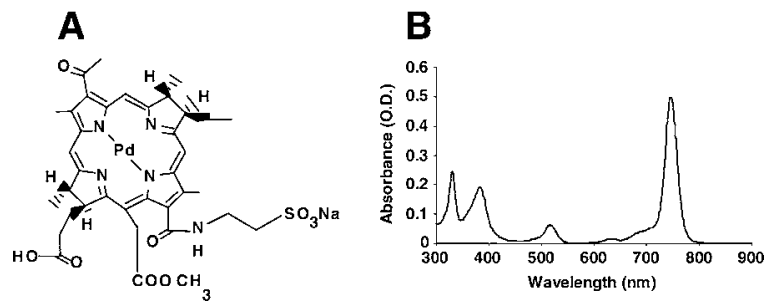

Figure 1. The chemical structure and absorption spectrum of WST11. (A) The chemical structure of WST11. (B) The absorption spectrum of WST11 $(5 \mu M)$ in methanol.

tumor (A. Brandis, O. Mazor, S. Gross, N. Koudinova, E. Gladysh, R. Hami, N. Kammhuber, V. Rosenbach-Belkin, M. Greenwald, A. Bondon, G. Simonneaux, H. Scheer, Y. Salomon and A. Scherz, personal communication, 13), with negligible skin phototoxicity (N. Koudinova, unpublished). Phase I-II clinical trials with Tookad ${ }^{\circledR}$ have been completed (20) and Phase II trials are in progress in several clinical centers in Canada, Europe and Israel against recurrent localized prostate cancer in patients who failed radiation therapy.

Because of low solubility of Tookad ${ }^{\circledR}$ in aqueous solutions (octanol-water partitioning is 24:1), its clinical application requires the use of amphiphilic vehicles such as Cremophor ${ }^{\circledR}(8)$. A wealth of recent experimental data have indicated that Cremophor ${ }^{\circledR}$ is a biologically and pharmacologically active compound and its use as a drug formulation vehicle has been implicated in clinically important adverse effects, including acute hypersensitivity reactions and peripheral neuropathy (21). Such possible effects may limit the maximal allowed doses of Tookad $\AA$ or its rate of administration (or both), particularly for the treatment of nonmalignant diseases. Furthermore, high hydrophilicity is usually associated with better retention in the circulation, as needed for vascular-targeted reagents. Therefore, it was desirable to prepare water-soluble Bchl derivatives with comparable photochemical properties and antivascular photodynamic activity.

In a recent study (A. Brandis, O. Mazor, E. Neumark, V. Rosenbach-Belkin, Y. Salomon and A. Scherz, personal communication, 22), we described the synthesis, solubility and optical spectroscopy of several new water-soluble derivatives of Bchl, substituted for $\mathrm{Pd}, \mathrm{Mn}$ and $\mathrm{Zn}$ atoms. We also provided the affinity of the new derivatives to serum proteins and showed the effect of serum albumin (SA) on their photocytotoxicity in endothelial cell cultures. Modification of Pd-Bpheid with taurine (2-sulfoethylenamine) resulted in a taurinated dianionic salt of Pd-Bchl (under the code name WST11, Fig. 1) (A. Brandis, O. Mazor, E. Neumark, V. Rosenbach-Belkin, Y. Salomon and A. Scherz, personal communication, 22) with an octanol-water partitioning coefficient of $2: 3$. This compound dissolves readily in phosphate-buffered saline (PBS) or water in the form of small aggregates (A. Brandis, O. Mazor, E. Neumark, V. Rosenbach-Belkin, Y. Salomon and A. Scherz, personal communication, 23) at concentrations $\leq 50 \mathrm{mg}$ / $\mathrm{mL}$. In solutions containing serum, WST11 undergoes disaggregation to monomers by adsorbing mostly to the SA $(>90 \%$ as $1: 1$, WST11-bovine serum albumin [BSA]) and high-density lipoprotein $(<10 \%)$ (A. Brandis, O. Mazor, E. Neumark, V. RosenbachBelkin, Y. Salomon and A. Scherz, personal communication, 23).

Binding to SA increases the probability of sensitizers to remain confined to the tumor vasculature, as required for VTP (24). However, the apparent photoactivity of the SA-bound WST11 against endothelial cells was found to be substantially different from noncomplexed pigment (A. Brandis, O. Mazor, E. Neumark, V. Rosenbach-Belkin, Y. Salomon and A. Scherz, personal communication, 22). This could either reflect a reduction in the concentration of free sensitizers able to enter the cells by fluid-phase endocytosis or BSA-mediated trafficking of the bound sensitizers via specific SA receptors in these cells $(25,26)$. The mode of endocytosis of WST11 into endothelial cells, its photocytotoxicity and the properties of its pharmacokinetics and biodistribution in vivo are probably key factors in determining its photodynamic efficacy and mode of action as an antivascular photosensitizer. Therefore, we set out to resolve these parameters to approach future developments and initiate appropriate treatment protocols for WST11-VTP.

The experiments presented in this study, combined with the assessment of WST11 phototoxicity under different SA concentrations (A. Brandis, O. Mazor, E. Neumark, V. Rosenbach-Belkin, Y. Salomon and A. Scherz, personal communication), provided evidence for SA-mediated cellular trafficking into endothelial cells. The temporal accumulation of WST11 in the lungs, along with its absence from the kidneys and the rapid hepatic clearance, provides additional indirect evidence for its interaction with SA. The pharmacokinetics, biodistribution and clearance rates of WST11 in mice and rats indicate a very short lifetime in the circulation with no significant extravasation into tissues. These findings suggest a rapid dissociation of the WST11-SA complex in target organs and corroborate the observed intermediate affinity of the sensitizer to the serum protein (A. Brandis, O. Mazor, E. Neumark, V. Rosenbach-Belkin, Y. Salomon and A. Scherz, in preparation, 22). Following our observations, the in vivo PDT protocol in animals was optimized to initiate illumination immediately after administrating the sensitizer. Under these conditions, WST11 was found to be a highly effective VTP reagent. Although, as reported in this study, this protocol was first tested with melanoma xenografts as a model (resulting in high cure rates), our data suggest that WST11 can be highly effective for VTP of other malignancies as well as nonmalignant diseases associated with abnormal vascularization such as age-related macular degeneration.

\section{MATERIALS AND METHODS}

Cell culture. M2R mouse melanoma and $\mathrm{H} 5 \mathrm{~V}$ mouse endothelial cells were cultured as monolayers in Dulbecco modified Eagle medium-F12 (Ham's F12 Nutrient Mix) containing $25 \mathrm{~m} M N$-[2-hydroxyethyl]piperazine- $N^{\prime}$-[2ethanesulphonic acid], $\mathrm{pH} 7.4,10 \%$ fetal calf serum (FCS), glutamine (2 $\mathrm{m} M)$, penicillin $(0.06 \mathrm{mg} / \mathrm{mL})$ and streptomycin $(0.1 \mathrm{mg} / \mathrm{mL})$ (hereafter referred to as the "culture medium"). Cells were grown at $37^{\circ} \mathrm{C}$ in an $8 \%$ $\mathrm{CO}_{2}$-humidified atmosphere.

Preparation of pigments. WST11 (molecular weight 940, Fig. 1) was derived from Pd-Bpheid (WST09) by aminolysis with taurine (2sulfoethylenamine; Aldrich; St. Louis, MO) as described earlier (A. Brandis, O. Mazor, E. Neumark, V. Rosenbach-Belkin, Y. Salomon and A. Scherz, personal communication) and kept dry in the dark under argon. Stock solutions of WST11 were prepared by dissolving the dry pigment directly in culture medium before use (for in vitro studies) or in PBS to the desired concentration for VTP in mice. Pigment purity and concentration were determined spectroscopically assuming $\varepsilon_{0}(\mathrm{MeOH})=1.2 \times 10^{5} M^{-1} \mathrm{~cm}^{-1}$ for WST11 using a Genesis-2 (Milton Roy; Rochester, NY) spectrophotometer.

Cellular pigment uptake. WST11, similar to other Pd-Bchl derivatives, presents extremely weak fluorescence complementary to its very high rate of intersystem crossing, as shown recently for Tookad ${ }^{\circledR}$ (Y. Vakrat and A. Scherz, personal communication). Therefore, the uptake of pigments by cells could not be determined by measuring fluorescence. Similarly, determination by optical absorption after extraction into methanol was found highly inaccurate at the lower concentration range. Because each WST11 molecule contains one Pd atom and its concentration can be determined to at least $1 \mathrm{ppb}$ with inductively coupled plasma mass spectroscopy (ICP-MS; ELAN-6000, Perkin Elmer; Boston, MA), we chose 
this mode of measurement as a viable alternative to determine the cellular content of Pd atoms under the selected experimental protocol. Importantly, the chelating of $\mathrm{Pd}^{2+}$ as a central metal within $\mathrm{Bchl}^{2-}$ macrocycle was found extremely stable in the range of $\mathrm{pH}$ 1-9 (data not shown) and under physiological conditions. Validation of the ICP-MS determination was carried out independently by comparing the Pd concentration in blood extracts with the WST11 concentration determined by its optical absorption in methanol (data not shown). Thus, cells were preincubated with the pigments for the indicated times, washed three times in PBS and collected using a rubber policeman.

The cells were then centrifuged (2000 rpm, $5 \mathrm{~min}$ ), resuspended in double-distilled water (DDW) and sonicated for $1 \mathrm{~min}$. The protein in each sample was determined by Coomassie blue assay (27). For Pd analysis, the samples were prepared as described below.

In vitro phototoxicity. To determine the pigment phototoxicity under standard conditions, cells were cultured in 96 well plates and preincubated in culture medium with the indicated concentrations of WST11 in the dark for $2 \mathrm{~h}$. To determine the cellular uptake of the pigment, the cells were preincubated with WST11 under different conditions as detailed in the individual experiments. Unbound sensitizer was then removed by washing the cells once with fresh warm culture medium, and the plates were illuminated at room temperature from the bottom for $10 \min (650<\lambda<800$ $\mathrm{nm}, 12 \mathrm{~J} / \mathrm{cm}^{2}$ ) using a $100 \mathrm{~W}$ halogen lamp (Osram; Munchen, Germany) equipped with a $<650 \mathrm{~nm}$ cutoff and a $4 \mathrm{~cm}$ water filter. The culture plates were then placed in the culture incubator and cell survival was determined $24 \mathrm{~h}$ after illumination, using the neutral red cell survival assay (28). The reliability of the neutral red assay for the evaluation of Bchl-based photodynamic activity was confirmed by a comparative study using the MTTthiazoyl blue assay. After subtraction of assay blanks, the net optical density $(570 \mathrm{~nm})$ was computed as the average value of triplicate determinations. Cell survival was calculated as the percentage of the dye that accumulated in the untreated controls. Experiments were conducted at least three times and representative experiments are shown. Three controls were used: (1) light control, cells illuminated in the absence of pigment; (2) dark control, cells treated with pigment but kept in the dark; and (3) untreated cells, cells kept in the dark.

Animals. Male CD1 nude mice ( 8 weeks old, $\sim 30 \mathrm{~g}$ ) or male WISTAR rats ( 6 months old, $\sim 250 \mathrm{~g}$ ) were housed with free access to food and water in the departmental animal facility. All experiments were conducted according to the guidelines of the institutional animal care and use committee of the Weizmann Institute of Science, Rehovot, Israel.

Anesthesia. Mice were anesthetized by an intraperitoneal (i.p.) injection of $80 \mu \mathrm{L}$ ketamine $(100 \mathrm{mg} / \mathrm{mL}$; Rhone Merieux, Lyon, France) and a xylazine (2\%; Vitamed, Benyamina, Israel) mixture (85:15, vol/vol). Rats were anesthetized by an i.p. injection of $300 \mu \mathrm{L}$ ketamine and a diazepam $\operatorname{mixture}(1: 1, \mathrm{vol} / \mathrm{vol})$.

Tumor model. Cultured mouse M2R melanoma cell monolayers were scraped under saline with a rubber policeman and implanted subcutaneously on the backs of the mice $\left(2 \times 10^{6}\right.$ cells/mouse, $\left.30 \mu \mathrm{L}\right)$; tumors developed to the treatment size (6-8 $\mathrm{mm}$ in diameter) within $2-3$ weeks.

Biodistribution. After i.v. injection of the WST11 $(6 \mathrm{mg} / \mathrm{kg})$, the mice were euthanatized at the indicated times and samples of the indicated organs or tissues were placed in preweighted vials and immediately frozen on dry ice. For examination, each sample was thawed and homogenized $(1: 10, \mathrm{wt} /$ vol) in DDW. Aliquots of the homogenate $(0.5 \mathrm{~mL})$ were lyophilized in 1.5 $\mathrm{mL}$ test tubes. To each dry sample, $\mathrm{HNO}_{3}(200 \mu \mathrm{L}, 70 \%$; TraceSelect, Fluka, Buchs, Switzerland) was added and the test tubes were incubated for $1 \mathrm{~h}$ at $90^{\circ} \mathrm{C}$. The acid-digested samples were then transferred to test tubes containing $10 \mathrm{~mL}$ of DDW. Pd concentrations in these samples were determined by ICP-MS. Background Pd levels in tissues were determined on equivalent tissue samples obtained from untreated mice. Experimental values were corrected respectively and the results are given as WST11 micrograms pigment per gram wet tissue (mean \pm SEM).

Pharmacokinetics. Anesthetized mice were i.v. injected with WST11 $(6 \mathrm{mg} / \mathrm{kg})$, and blood samples $(\sim 50 \mu \mathrm{L})$ were drawn from the tail vein at the indicated times, placed in preweighed $1.5 \mathrm{~mL}$ test tubes, weighted and lyophilized.

For infusion studies, rats were catheterized in the femur and tail veins. WST11 $(10 \mathrm{mg} / \mathrm{kg})$ was then infused for $20 \mathrm{~min}$ into the tail vein by a dedicated infusion pump, and blood samples $(\sim 100 \mu \mathrm{L})$ were drawn from the femur vein at the indicated times, placed in preweighed $1.5 \mathrm{~mL}$ test tubes, weighed and lyophilized. Samples from both experiments were then prepared for Pd determination as described above.
VTP protocol. The M2R tumor-bearing mice were anesthetized and WST11 ( 6 or $9 \mathrm{mg} / \mathrm{kg}$ ) was injected i.v. via the tail vein. The tumors were immediately transcutaneously illuminated for 5 min using a $755 \mathrm{~nm}$ diode laser (CeramOptec, Germany) at the indicated light doses. After treatment, the mice were returned to the cage. The mice were considered cured if tumor free for 90 days after treatment. Mice were euthanatized when the tumor diameter reached $15 \mathrm{~mm}$. The controls used were (1) dark control, the mice were i.v. injected with pigment and not illuminated; (2) light control, mice were illuminated without pigment injection; and (3) untreated control.

Statistical analyses. Triplicate determinations were performed in cell survival analyses and presented as the average \pm SEM. All experiments were performed at least three times and representative examples are presented.

\section{RESULTS AND DISCUSSION}

\section{Cellular uptake of WST11}

To study the effect of temperature upon sensitizer uptake, endothelial $\mathrm{H} 5 \mathrm{~V}$ cells (Fig. 2A) and M2R melanoma cells (Fig. 2B) were incubated at $4^{\circ} \mathrm{C}$ or $37^{\circ} \mathrm{C}$ with $10 \mu M$ WST11, washed at the indicated times and analyzed for Pd content. As shown, pigment association at $37^{\circ} \mathrm{C}$ increased rapidly during the first 5-10 min and then leveled off at $\sim 50-60 \mathrm{~min}$ after the beginning of the incubation. In contrast, at $4^{\circ} \mathrm{C}$, WST 11 rapidly associated with the cells and leveled off at $10 \mathrm{~min}$ at lower concentrations.

The amount of cell-associated WST11 (Fig. 2A) arrives at a steady state in approximately $45 \mathrm{~min}$. Pigment accumulation can be described by the following equation:

$$
\mathrm{d}[\mathrm{WST} 11]_{\text {in }} / \mathrm{dt}=\mathrm{Y}-k[\mathrm{WST} 11],
$$

where $\mathrm{d}[\mathrm{WST} 11]_{\text {in }} / \mathrm{dt}=0$ after $\sim 45 \mathrm{~min}$ of preincubation.

The solution of Eq. 1a is

$$
[\mathrm{WST} 11]_{\mathrm{in}}=\mathrm{Y} / k\left(1-e^{-k \mathrm{t}}\right)
$$

where $k$ (in $\min ^{-1}$ ) represents the rate constant for the sensitizer's efflux from the endothelial cells and Y represents the rate of the sensitizer's influx into the cells. This equation fits the experimental data regarding the temporal concentration of WST11 in the cells after incubation at $37^{\circ} \mathrm{C}$ with $k=0.0946 \pm 0.0331 \mathrm{~min}^{-1}$ (Fig. 2A, solid line). Notably, Eq. $1 \mathrm{~b}$ can also be interpreted in terms of a Langmuir adsorption curve, as discussed below.

We next determined how the presence of serum affects WST11 uptake by M2R cells at low and high temperatures. Figure $2 \mathrm{C}$ shows that short incubation $(10 \mathrm{~min})$ of the cells with $10 \mu M$ WST11 at $37^{\circ} \mathrm{C}$ in the presence of serum decreased $\mathrm{Y} / k$ by a factor of 3-5 compared with cells incubated without serum. In contrast, the presence of serum had only a slight effect on WST11 uptake at $4^{\circ} \mathrm{C}$ (Fig. 2C). On the basis of these experiments, we concluded that WST11 is taken up by the cells in two modes; the first is strongly affected by serum and is inhibited by low temperature, whereas the second is independent of serum and is maintained at low temperature. The temperature dependence of pigment uptake in the presence of serum suggests that active uptake takes place at $37^{\circ} \mathrm{C}$, in agreement with endocytosis of other albumin-bound drugs, as described by others (29).

The association of WST11 at $4^{\circ} \mathrm{C}$ with both M2R and H5V cells in the presence or absence of serum was nonphototoxic on illumination, whereas $80 \%$ of cell death was induced after preincubation with WST11 at $37^{\circ} \mathrm{C}$ (Fig. 3). Notably, low temperatures were found to affect both active and passive pinocytosis of molecules of the WST11 size (as mentioned, WST11 forms small aggregates of 1-2 $\mathrm{nm}$ in diameter in the absence of serum) but not their adsorption to the cell membrane (29). Therefore, we propose 

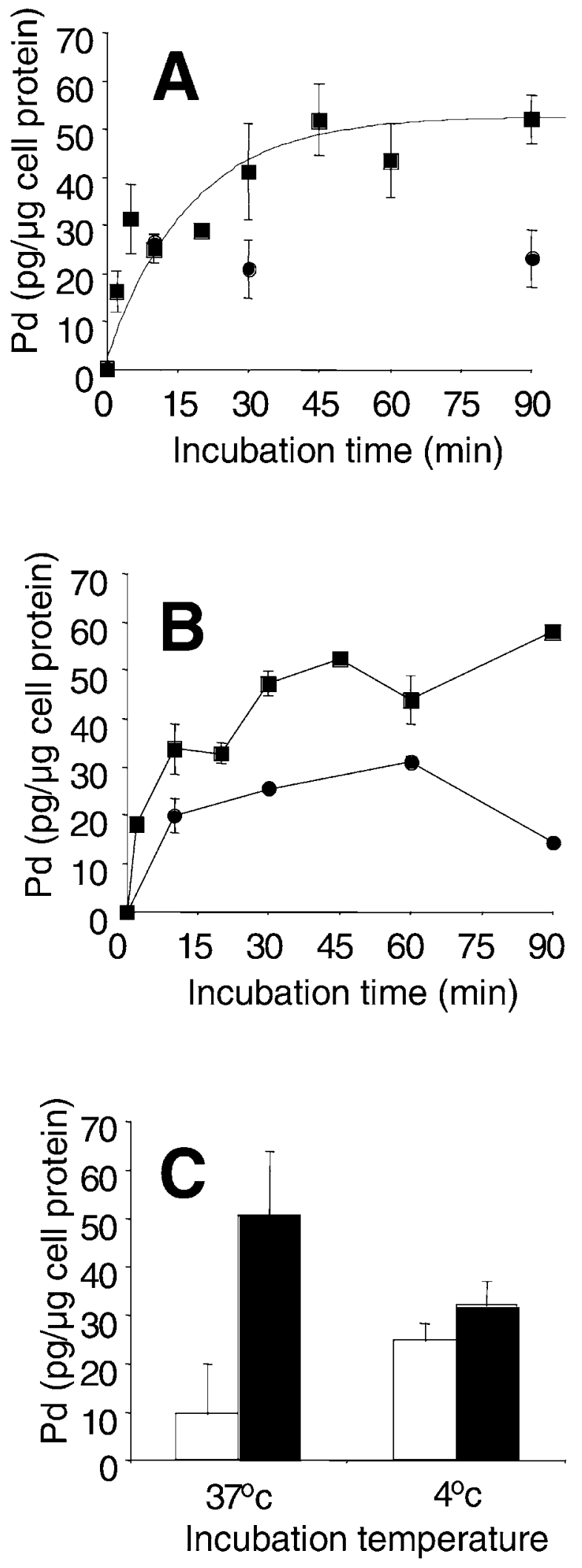

Figure 2. Cellular uptake of WST11. H5V (A) or M2R (B) cells were preincubated with $10 \mu M$ WST11 at $37^{\circ} \mathrm{C}$ (squares) or $4^{\circ} \mathrm{C}$ (circles) for the indicated time periods, washed three times and collected. (C) M2R cells were preincubated for 10 min with $10 \mu M$ WST 11 at $37^{\circ} \mathrm{C}$ or $4^{\circ} \mathrm{C}$ in the absence (empty bars) or presence (filled bars) of $10 \%$ FCS, washed three

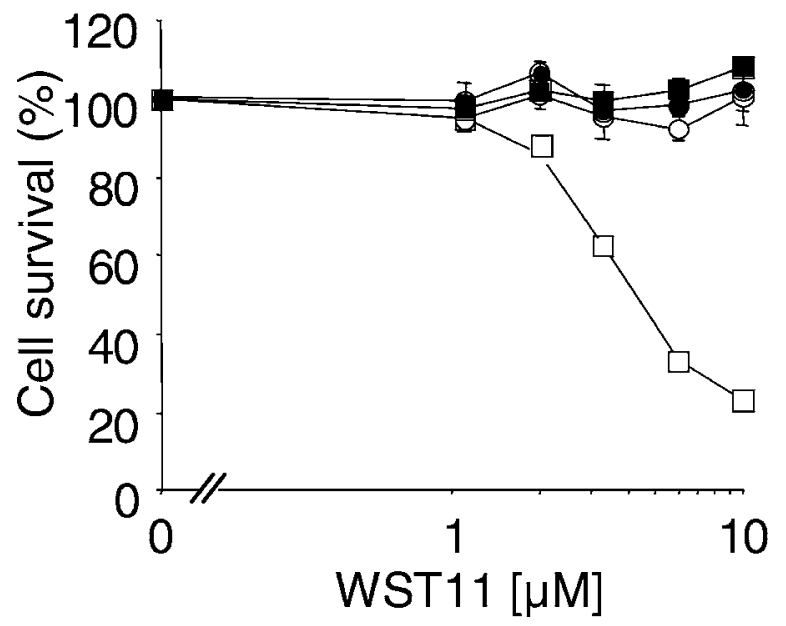

Figure 3. Inhibition of WST11 phototoxicity at low temperature. H5V cells were preincubated with the indicated increasing concentrations of WST1 1 at $37^{\circ} \mathrm{C}$ (squares) or $4^{\circ} \mathrm{C}$ (circles), washed and illuminated (open shapes) or kept in the dark (closed shapes). The points are the mean \pm SEM of triplicate determinations.

that excitation of WST11 after preincubation at $4^{\circ} \mathrm{C}$ does not confer phototoxicity because the pigment localizes in sites that are not critically affected by ROS, possibly on the outer surface of the cell membrane. On the other hand, at $37^{\circ} \mathrm{C}$, WST11 molecules reach appropriate targets for initiating phototoxic processes.

The phototoxicity of WST11 depends on the concentration of SA during preincubation

WST11 was shown to complex with BSA $\left(\mathrm{K}_{\mathrm{assoc}} \sim 10^{4} \mathrm{M}^{-1}\right)$, and similar binding was obtained with human serum and with purified human SA (A. Brandis, O. Mazor, E. Neumark, V. RosenbachBelkin, Y. Salomon and A. Scherz, personal communication). This complexation of WST11 should affect the cellular uptake, clearance rate and biodistribution of the pigment and consequently its phototoxicity and biological activity. Whereas unbound, free WST11 can undergo receptor-independent, fluid-phase pinocytosis, the SA-bound pigment may be subject to SA- or receptormediated trafficking (26). Notably, binding of other photosensitizers to SA but with significantly higher affinity constants (e.g. $2 \times$ $10^{8} M^{-1}$ for hydroxyethyl-vinyl-deuteropophyrin [30]) could be detrimental to its photocytotoxicity, as demonstrated for Chlorin $e_{6}$ derivative (Npe6) in P388 murine leukemia cells (31). The effect of serum proteins on the cellular uptake and photocytoxicity of PDT sensitizers is particularly important when considering treatment protocols for those that clear rapidly. Hence, we set out to study this effect with WST11.

The phototoxicity of WST11 was markedly attenuated if serum proteins were present during preincubation (Fig. 4A). The apparent $\mathrm{LD}_{50}$ of WST11 increased from $\sim 1 \mu M$ after $2 \mathrm{~h}$ of preincubation in the absence of serum to $\sim 4 \mu$ in $10 \%$ FCS medium (10\% FCS contains $\sim 60 \mu M$ BSA), with no dark toxicity in the tested concentration range. A similar shift was observed when WST11 was preincubated in the presence of increasing BSA concentrations (Fig.

times and collected. Pd concentrations were determined by ICP-MS. The points are the mean \pm SEM of triplicate determinations. All other details were as described under Materials and Methods. 

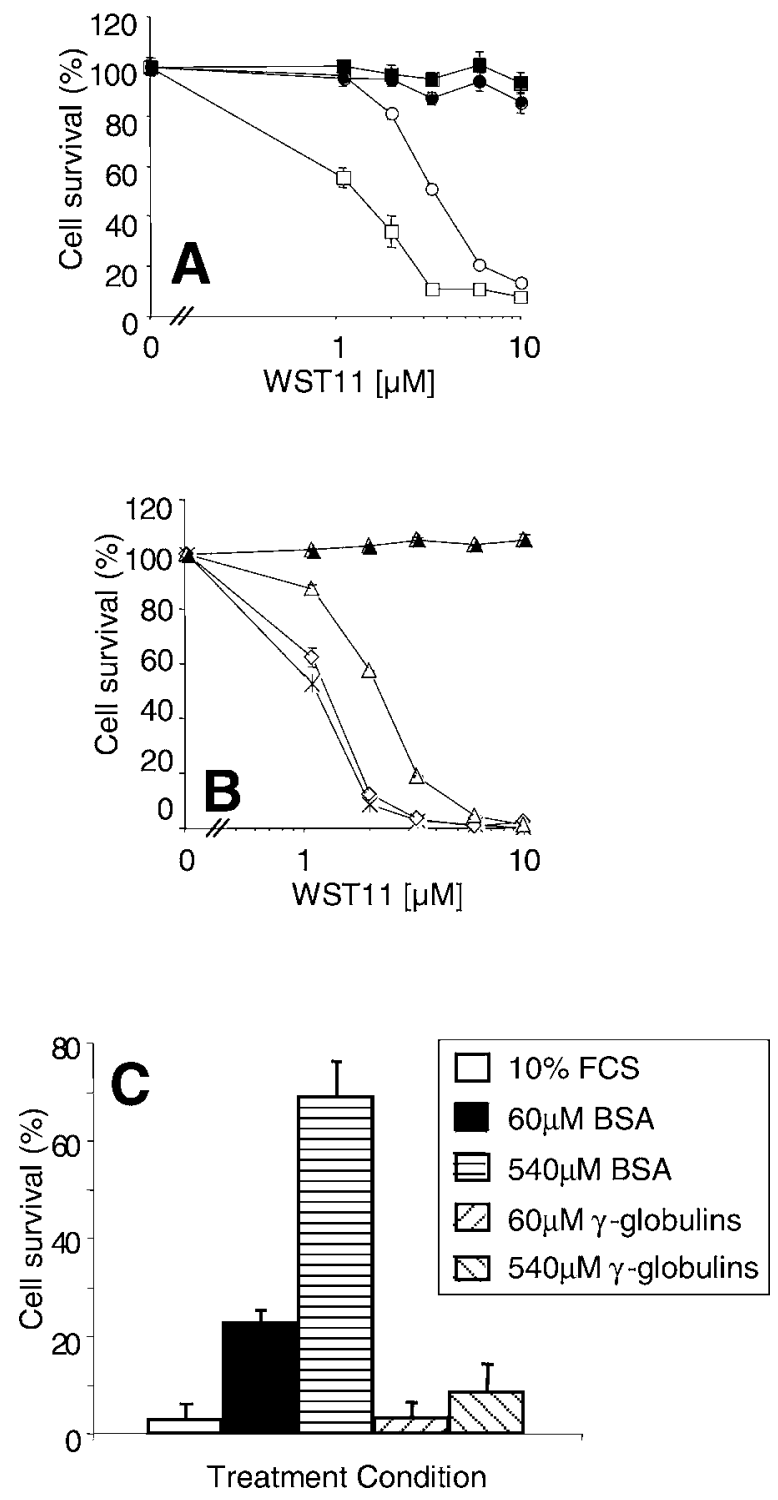

Figure 4. The effect of serum and BSA on WST11 phototoxicity. H5V cells were preincubated for $2 \mathrm{~h}$ with the indicated increasing concentrations of WST11 in (A) the absence (squares) or presence (circles) of $10 \%$ FCS or (B) in the absence or presence of BSA, $2 \mu M$ (circles), $10 \mu M$ (squares) or $60 \mu M$ (triangles) or (C) in the presence of $\gamma$-globulins. Cells were then washed with fresh medium and illuminated (open shapes) or kept in the dark (closed shapes). Points are mean \pm SEM of triplicate determinations.

4B). To confirm that the effect on the phototoxicity of WST11 is specific for BSA, cells were preincubated with WST11 in the presence of 60 or $540 \mu M$ bovine $\gamma$-globulins, washed and illuminated. As shown in Fig. 4C, the presence of $\gamma$-globulins had only a minor effect on the WST11 phototoxicity. The preferred affinity of WST11 to BSA was further demonstrated in concentrated solutions of WST11 where the addition of BSA resulted in complete monomerization of the sensitizer, while no such effect was observed on adding $\gamma$-globulin (A. Brandis, O. Mazor, E. Neumark, V. Rosenbach-Belkin, Y. Salomon and A. Scherz, personal communication). Considering that phototoxicity can serve as a measure of pigment uptake, these findings suggest that binding to BSA (1) markedly reduces cellular uptake of WST11 as found for other phtosensitizers because of reduction in free pigment con-

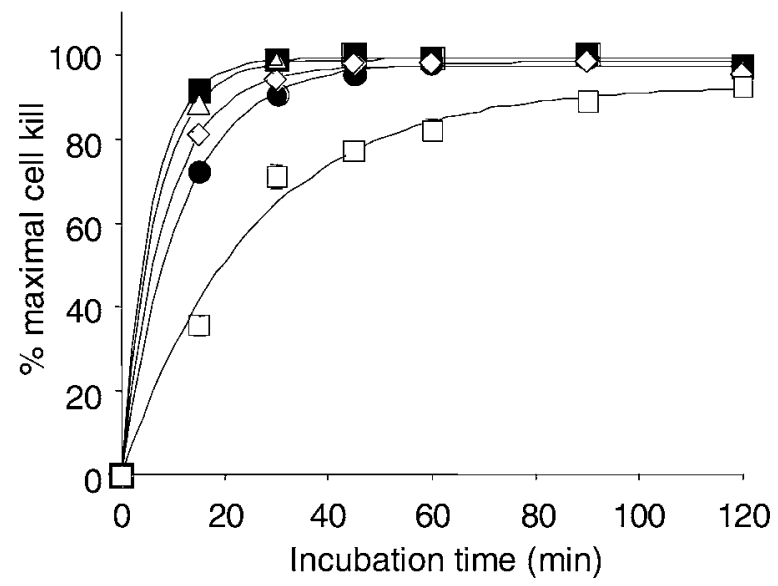

Figure 5. The effect of serum and BSA on WST11 uptake kinetics. H5V cells were preincubated for the indicated time periods with $10 \mu M$ WST11, washed and illuminated. Preincubation conditions were the absence (filled squares) or presence of serum (filled circles) or BSA, $2 \mu M$ (triangles), 10 $\mu M$ (diamonds) and $60 \mu M$ (open squares). The results are presented as the percentage of maximal cell killing. The points are the mean \pm SEM of triplicate determinations.

centrations $(31,32)$ or $(2)$ completely wipes out the phototoxicity of WST11 so that no photoxicity is conferred even if the pigment enters the cells, as suggested for the Npe6 in P388 leukemia cell suspension (31) (or both). Following this alternative, the percentage but not the rate of phototoxicity evolution should be affected by SA.

Figure $2 \mathrm{C}$ shows that the addition of BSA markedly reduced the total amount of WST11 taken up by $\mathrm{H} 5 \mathrm{~V}$ cells at $37^{\circ} \mathrm{C}$. To study the effect of BSA on the uptake kinetics of WST11, we determined cell survival by monitoring increasing preincubation times with $10 \mu M$ WST11 in the absence or presence of $10 \%$ FCS or BSA (2-60 $\mu M$ ) (Fig. 5).

Clearly, the rate for the evolution of photocytotoxicity decreased with increasing concentrations of BSA. The fastest rate of cell killing was observed in the absence of added proteins, whereas in the presence of increasing BSA concentrations, this killing rate was attenuated progressively (Table 1). Complete cell killing was attained with $60 \mu M$ BSA (the BSA concentration provided also by $10 \%$ FCS) only after $120 \mathrm{~min}$ of preincubation. This observation rules out alternative (2) as a possible mechanism.

The temporal evolution of phototoxicity can be simulated (Fig. 5 , solid lines) by the equation

$$
\mathrm{T}(\mathrm{t})^{*}=100 \%\left(1-\mathrm{e}^{-k_{2} \mathrm{t}}\right),
$$

where $T(t)$ represents the fraction (in percent) of photointoxicated cells at $\mathrm{t}$ min after starting preincubation and $k_{2}$ is the rate constant for the evolution of phototoxicity. Apparently, at increased concentrations of SA (either as part of FCS or when added in a purified

Table 1. Uptake parameters of WST11 in H5V cells under different medium conditions

\begin{tabular}{lr}
\hline Medium condition & $k_{2}\left(\mathrm{~min}^{-1}\right)$ \\
\hline $10 \%$ FCS & $0.088 \pm 0.002$ \\
Without FCS & $0.172 \pm 0.011$ \\
$2 \mu M$ BSA & $0.148 \pm 0.007$ \\
$10 \mu M$ BSA & $0.117 \pm 0.005$ \\
$60 \mu$ BSA & $0.04 \pm 0.005$ \\
\hline
\end{tabular}




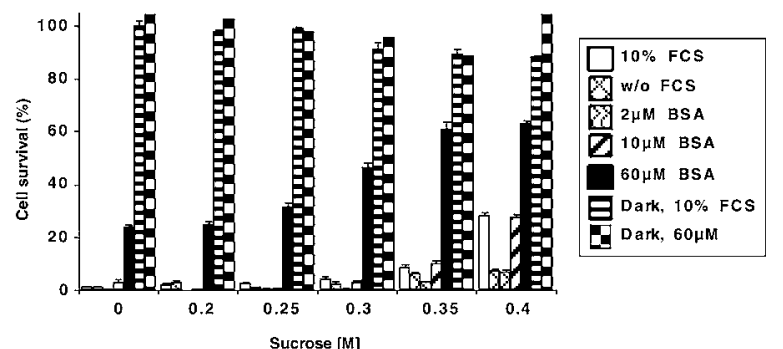

Figure 6. Inhibition of photocytotoxicity by sucrose. $\mathrm{H} 5 \mathrm{~V}$ cells were preincubated for $2 \mathrm{~h}$ with increasing concentrations of sucrose and $10 \mu \mathrm{M}$ WST11 in the presence of the indicated BSA or FCS concentrations, washed once with fresh medium and illuminated or kept in the dark. The bars are the mean \pm SEM of triplicate determinations.

form) $k_{2}$ decreased and the phototoxicity of WST11 reached saturation at longer times. The simplest explanation for this phenomenon, considering the above-mentioned formation of a complex between WST11 and SA, is that cellular uptake of the photosensitizer follows Langmuir adsorption to a limited number of sites (eventually SA receptors), $\mathrm{N}$, at the cell membrane. Consequently, Eq. 2 is the solution for Eq. 3

$$
\mathrm{dx} / \mathrm{dt}=k_{\mathrm{ad}}[\mathrm{WST} 11][\mathrm{N}-\mathrm{f}(\mathrm{SA})](1-x),
$$

where $k_{\text {ad }}$ is the adsorption rate constant of the SA-WST11 complex, [WST11] is the sensitizer concentration outside the cell, $\mathrm{N}$ is the total number of SA receptors, $\mathrm{f}(\mathrm{SA})$ is the fraction of receptors bound to noncomplex SA and $x$ is the fraction of receptors free for binding SA-WST11. Thus, $k_{2}=k_{\mathrm{ad}}[\mathrm{WST} 11][\mathrm{N}-\mathrm{f}(\mathrm{SA})]$. Evidently, on increasing [SA] in the preincubation medium, $\mathrm{f}(\mathrm{SA})$ increases and $k_{2}$ decreases as observed (Table 1, Fig. 5). Thus, the formation of a complex with BSA affects both the overall concentration of free pigments and rate of WST11 uptake by $\mathrm{H} 5 \mathrm{~V}$ cells, probably in a receptor-mediated fashion. In fact, approaching physiological SA concentrations, there is practically very little uptake of WST11 within the first few minutes of incubation (A. Brandis, O. Mazor, E. Neumark, V. Rosenbach-Belkin, Y. Salomon and A. Scherz, personal communication).

\section{The photocytotoxicity of WST11 becomes sucrose dependent in the presence of albumin}

To verify the significance of the formation of the WST11-BSA complex to the photodynamic activity with WST11, we examined the phototoxicity of the sensitizer under conditions that should affect albumin endocytosis but not the cellular uptake of free WST11. Hypertonic conditions, encouraged by high sucrose concentrations, affect the endocytosis of SA (33-35), although it is traditionally considered as a marker for fluid-phase endocytosis (pinocytosis). Remarkably, when incubated in the presence of $0.2 \mathrm{M}$ sucrose, the rate of $\left[{ }^{125} \mathrm{I}\right]-$ tyramine cellobiose-labeled BSA accumulation in hepatocytes declined by $\sim 50 \%$ compared with controls containing no sucrose (36).

Figure 6 shows the effect of increased sucrose concentration on the phototoxicity of WST11. In the absence of serum, the phototoxicity of WST11 was almost unaffected by sucrose $(0-0.4 M)$. However, in the presence of BSA $(\geq 10 \mu M)$, the phototoxicity of WST11 significantly declined with increasing sucrose concentrations ( $25 \%$ cell survival at $0.4 M$ sucrose). At $60 \mu M$ BSA and $0.4 M$ sucrose as in $10 \%$ FCS, cell survival increased to $\sim 65 \%$. Notably, the effect of sucrose on the temporal evolution of photocytotoxicity and its maximal value reported in this study appear similar to the
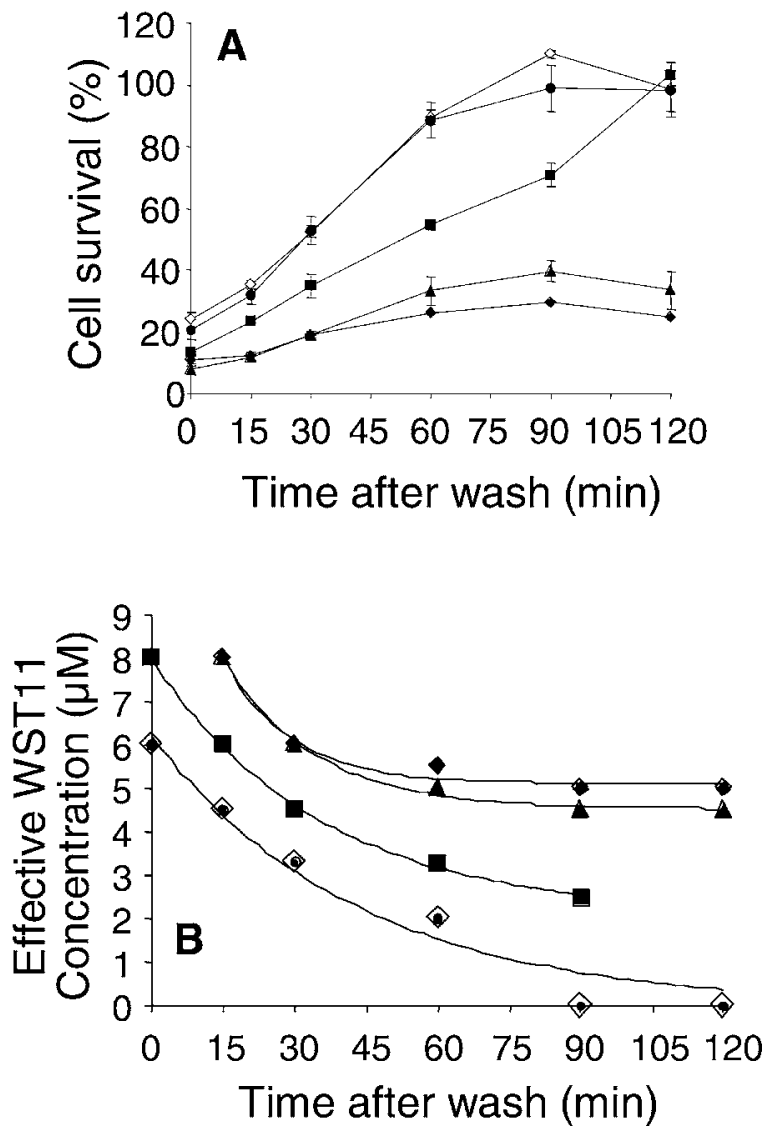

Figure 7. The effect of FCS and BSA on WST11 exocytosis rates. (A) $\mathrm{H} 5 \mathrm{~V}$ cells were preincubated for $2 \mathrm{~h}$ with $10 \mu M$ WST11 in medium containing 10\% FCS (comprising $\sim 60 \mu M$ BSA). Cells were then washed and further incubated under different medium conditions without WST11. Cells were illuminated thereafter at the indicated time points. The medium conditions were the absence (filled diamonds) or presence (open diamonds) of serum, $2 \mu M$ (filled triangles), $10 \mu M$ (filled squares) or $60 \mu M$ (filled circles) of BSA. The points are the average of triplicates \pm SEM. (B) Each experimental point of (A) was translated to effective WST11 concentrations on the basis of Fig. 3 as a calibration curve. The lines were fitted according to Eq. 3.

previously reported effect of this agent on the kinetics of SA accumulation and its steady-state concentration in cells (35). This finding provides additional support to our hypothesis that in the presence of SA, the majority of WST11 enters the cells as WST11BSA complexes and very little as free WST11, which was found to be sucrose independent.

\section{Exocytosis of WST11: effects of serum proteins and albumin}

To further explore the role of serum proteins or SA in WST11 cell trafficking, we performed the following set of experiments: H5V cells were preincubated with $10 \mu M$ WST11 in $10 \%$ FCS for $2 \mathrm{~h}$, followed by replacing with a WST11-free medium but with different concentrations of BSA. Cells were then illuminated at different times after medium change and cell survival was determined. As shown in Fig. 7A, cell survival after medium replacement leveled off at values positively correlated with the BSA concentrations. In the presence of up to $2 \mu M$ BSA, cell survival increased from $10 \%$ to $30 \%$ within 60 min without any further change. In the presence of higher BSA concentrations, cell survival reached $90 \%$ after 60 min (for $60 \mu M$ BSA and $10 \%$ FCS) or $100 \%$ at $120 \mathrm{~min}$ (for $10 \mu M$ BSA). 
Table 2. Exocytosis parameters of WST11 in H5V cells under different medium conditions

\begin{tabular}{lc}
\hline Medium condition & $k_{3}\left(\mathrm{~min}^{-1}\right)$ \\
\hline $10 \%$ FCS & $0.023 \pm 0.005$ \\
Without FCS & $0.071 \pm 0.019$ \\
$2 \mu M$ BSA & $0.053 \pm 0.007$ \\
$10 \mu M$ BSA & $0.029 \pm 0.003$ \\
$60 \mu M$ BSA & $0.023 \pm 0.005$ \\
\hline
\end{tabular}

To further illustrate this point, cell survival under each condition, as shown in Fig. 7A, was translated into the level of phototoxicity induced by effective concentrations of ambient WST11 in the preincubation step (Fig. 7B), taking the results of Fig. 3 as a calibration curve. The variation in the effective concentration of WST11 could be well fitted with a simple exponential equation,

$$
\text { [WST11] }=a+b \exp \left(-k_{3} \mathrm{t}\right)
$$

where $k_{3}$ stands for the rate of cell detoxification, "a" represents a fraction of WST11 that cannot be cleared from the preincubated cells and " $b$ " stands for the cleared fraction. The exocytosis parameters are summarized in Table 2, and as can be seen, increasing the BSA concentrations decreased a while increasing $b$. The rate constant, $k_{3}$, appeared to remain practically constant at $\geq 10 \mu M$ BSA, and it significantly increased at low or null BSA concentrations.

On the basis of these observations, we speculated that deactivation of WST11 during exocytosis involves binding to BSA molecules that undergo continuous endocytosis and exocytosis. Thus, the BSA molecules serve as a carrier for exocytosis of WST11 molecules from endothelial cells to the extracellular space where they dilute. Increasing the BSA concentration in the medium after incubation should enhance this mobilization, as shown in Fig. 7. Interestingly, binding to BSA appears essential for cellular detoxification after washing because phototoxicity seems to remain for a long time in the absence of external WST11 concentrations (Fig. 7). Moreover, the exocytosis rate in the absence of BSA is higher (Table 2), but this process can remove only a small fraction of the WST11 from the cell. The dependence of cell survival on BSA, as shown in this study, suggests the active involvement of this serum protein in the trafficking of WST11 both into and out of the treated cells. Taking that observation into consideration, we propose that under conditions where physiologically relevant BSA concentrations $(\geq 60 \mu M)$ are present the uptake and release of WST11 by $\mathrm{H} 5 \mathrm{~V}$ cells is mostly, if not completely, BSA mediated. However, on the basis of the equilibrium constant for BSA-WST11 association $\left(\mathrm{K} \sim 10^{4} M^{-1}\right.$ ), the incubating medium at $60 \mu \mathrm{M}$ BSA and $10 \mu M$ WST11 should contain $\sim 4 \mu M$ of free WST11, a much higher concentration than $\mathrm{LD}_{50}$ in a BSA-free solution. This paradoxical finding may be explained by assuming that the BSA concentration is increased locally in the cell membrane compartments during internalization. Having WST11 exposed to increased BSA concentrations in the fluid phase of early endosomes should shift the equilibrium toward further association of WST11 with BSA molecules. Thus, we propose that although the external concentration of free WST11 is significant, it markedly decreases on entering the cells because of intracellular binding to BSA or other intracellular proteins. To gain phototoxicity, the SA-WST11 complexes probably have to enter the lysosomes where they most likely dissociate. Indeed, accumulation of other hydrophilic sensitizers in the lysosomes was reported previously (37-39).

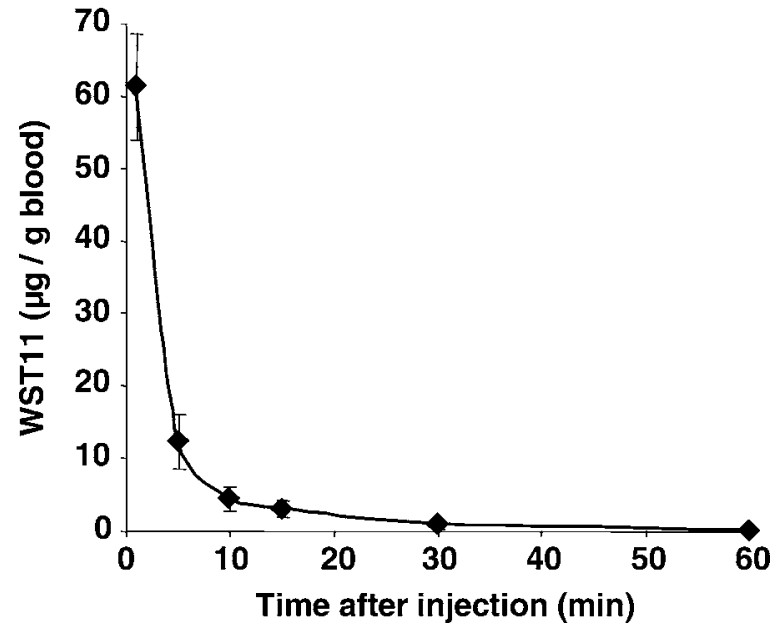

Figure 8. Clearance rate of WST11 in mouse blood after i.v. injection. WST11 (6 mg/kg) was i.v. injected into CD1 nude mice, and blood samples were taken from the tail vein at the indicated times. WST11 concentrations (dots) were determined (by ICP-MS of Pd) and given as micrograms WST11 per gram blood. Other details were as described in the Materials and Methods section. The values are the mean \pm SEM of three mice. The solid line shows the theoretical fit using Eq. 5.

Our data suggest that exocytosis of WST11 from H5V cells includes at least two steps (36) involving $\mathrm{X}_{2} \rightarrow \mathrm{X}_{3} \rightarrow \mathrm{X}_{4}$, where the first step comprises the conversion of a free phototoxic WST11 $\left(\mathrm{X}_{2}\right)$ into a nonphototoxic BSA-bound complex entrapped in plasmallema-derived vesicles $\left(X_{3}\right)$. In the second step, these vesicles return to the plasmalemma membrane $\left(\mathrm{X}_{4}\right)$ and undergo extravasation.

In all, WST11 distribution in endothelial cells is proposed to be a four-step process: $X_{1} \rightarrow X_{2} \rightarrow X_{3} \rightarrow X_{4}$, where $X_{1}$ and $X_{4}$ represent WST11-SA complexes available for endocytosis and exocytosis, respectively. This scheme is a variant of the three-step Poison jump process suggested by Niles and Malik (36) to describe a particulate dye distribution in endothelial cells, where new vesicles were found to enter state $X_{2}$ at a rate given by Eq. 2 .

\section{Pharmacokinetics of WST11 in mice}

VTP with Tookad ${ }^{\circledR}$ and WST11 aims at shutting down the tumor blood supply (A. Brandis, O. Mazor, S. Gross, N. Koudinova, E. Gladysh, R. Hami, N. Kammhuber, V. Rosenbach-Belkin, M. Greenwald, A. Bondon, G. Simonneaux, H. Scheer, Y. Salomon and A. Scherz, personal communication, 11,40). In this protocol, the tumor is illuminated when the drug concentration in the blood is high, i.e. immediately after drug injection. To determine the clearance rate of WST11 from the circulation, the drug was bolus i.v. injected into nude mice $(6 \mathrm{mg} / \mathrm{kg})$ and blood samples were taken from the tail vein at various time points thereafter. Figure 8 shows the clearance of WST11 from the blood after injection. The kinetics is monoexponential

$$
\mathrm{y}=\mathrm{a}+\mathrm{b} \exp ^{(-k \mathrm{t})}
$$

with $t_{1 / 2}=1.65 \mathrm{~min}$. Approximately $90 \%$ of the injected pigment cleared within $5 \mathrm{~min}$, reaching almost background levels $30 \mathrm{~min}$ after injection. The corresponding rate of elimination $\left(\mathrm{K}_{\mathrm{el}}\right)$ was $0.42 \mathrm{~min}^{-1}$, the volume of distribution $\left(\mathrm{V}_{\mathrm{d}}\right)$ was $2.12 \mathrm{~mL}$ and the clearance rate was $0.89 \mathrm{~mL} / \mathrm{min}$. 


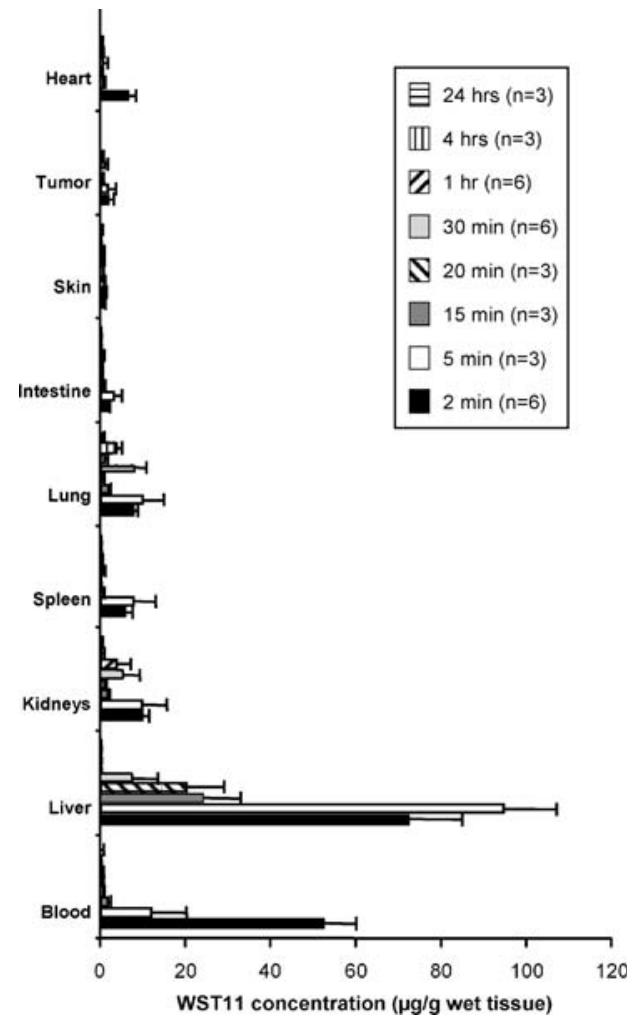

Figure 9. Biodistribution of WST11 in mice bearing melanoma xenografts. Mice were euthanatized at different times after i.v. injection of WST11 $(6 \mathrm{mg} / \mathrm{kg})$, and WST11 content in the respective tissue samples were determined (by ICP-MS of Pd) and presented as micrograms WST11 per gram wet tissue, as described in the Materials and Methods section. The values for each time point represent the mean \pm SEM of three to six animals. Value for brain, testes, fat and muscle are not presented, yet found to be below $5 \mu \mathrm{g} / \mathrm{g}$ wet tissue.

\section{WST11 does not extravasate from the circulation and rapidly clears from the animal body}

Figure 9 shows the biodistribution of WST11 in M2R melanomabearing mice after bolus i.v. administration $(6 \mathrm{mg} / \mathrm{kg}$ body). The highest levels of WST11 in the blood were found immediately after injection ( $2 \mathrm{~min}$ ) and in the liver, kidney, lung and spleen only $5 \mathrm{~min}$ after injection. Clearance of WST11 was completed in all these tissues by $60 \mathrm{~min}$ but in the lungs by $4 \mathrm{~h}$ with only background levels remaining $24 \mathrm{~h}$ after administration in any of the examined tissues. The clearance rate of WST11 from the lung $\left(\mathrm{t}_{1 / 2} \sim 40 \mathrm{~min}\right)$ was markedly slower than from other tissues and significantly slower than from the liver $(\sim 20 \mathrm{~min})$. The biodistribution and rate of clearance of WST11 from tissues may be related to water solubility and the negative charges introduced by the taurine side group and its complexation with SA (41). Taurine is a $\beta$-amino acid normally present in the intracellular fluid, and it is widely distributed in many tissues including the brain, retina and liver of mammals (42). It appears to be involved in brain and retinal development, osmoregulation, detoxification and xenobiotic conjugation. Conjugation of taurine to different molecules in the liver in the course of their detoxification increases their polarity and aqueous solubility, thereby facilitating their hepatic clearance (42). Thus, the rapid clearance of WST11 from the liver compared with that of Tookad ${ }^{\circledR}\left(\mathrm{t}_{1 / 2}=\sim 5 \mathrm{~h}\right.$ in the liver) could be anticipated. The temporal accumulation of WST11 in the lungs is probably related to its association with SA and

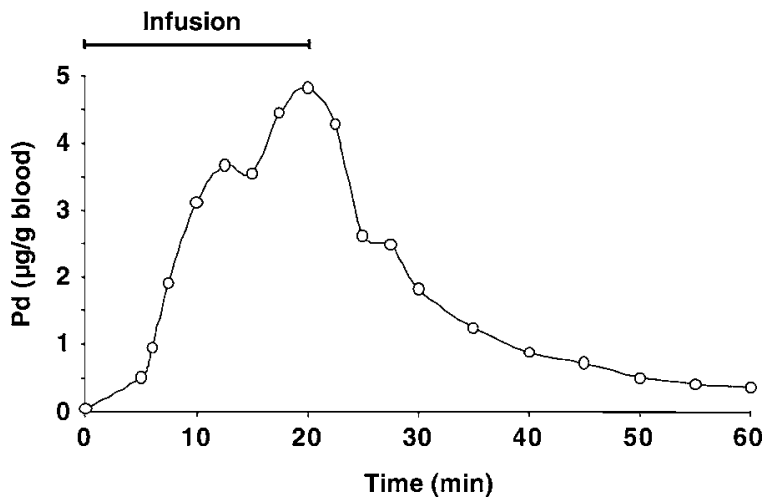

Figure 10. Blood levels of WST11 during and after infusion. WISTAR rats were infused for $20 \mathrm{~min}$ with WST11 $(10 \mathrm{mg} / \mathrm{kg})$, and blood was drawn at the indicated time points. WST11 concentrations were determined by ICPMS for Pd. The graph is a representative example of one rat (out of three).

its transcellular trafficking through the caveoli of endothelial cells in this organ (43). The significant differences in structure between the polar WST11 and the hydrophobic Tookad ${ }^{\circledR}$ may therefore be reflected in their different biodistribution and pharmacokinetics. The rapid elimination of WST11 from the blood without accumulation in the skin assures the absence of coetaneous phototoxicity, as was found for Tookad ${ }^{\circledR}$ (A. Brandis, O. Mazor, S. Gross, N. Koudinova, E. Gladysh, R. Hami, N. Kammhuber, V. Rosenbach-Belkin, M. Greenwald, A. Bondon, G. Simonneaux, H. Scheer, Y. Salomon and A. Scherz, personal communication).

\section{Infusion of WST11 can extend its presence in the circulation}

As shown previously, WST11 clears rapidly from the circulation, leaving only a short time-window for illumination where pigment levels in the blood are photodynamically effective. This may pose some technical difficulties in the PDT protocol in large animals and humans where manipulations of surgical gear may not be so fast. Thus, extension of the effective time-window may be achieved by sensitizer infusion without increasing the total drug dose delivered. Theoretically, by infusion, drug levels will reach their maximum in the blood within $4.3 \mathrm{t}_{1 / 2}$ and will remain so during a constant infusion rate (41). On termination of infusion, the drug is expected to clear with its inherent clearance rate. Changing the rate of infusion or the injected dose will affect the maximal circulating levels reached without changing the time needed to attain a maximal level (38).

To test the feasibility of this approach, we infused WST11 to rats for $20 \mathrm{~min}$ and its circulating levels were monitored by blood sampling at the indicated time points (Fig. 10) followed by determination with ICP-MS. Figure 10 shows that the WST11 concentration in the blood increased initially for $\sim 20 \mathrm{~min}$ and started to level off without reaching a steady-state concentration by the end of the infusion. Immediately after the infusion was stopped, WST11 cleared according to a monophasic behavior according to Eq. 8. The calculated $t_{1 / 2}$ of WST11 after infusion was found to be $7.12 \pm 0.37 \mathrm{~min}(\mathrm{n}=3)$. Thus, $40 \mathrm{~min}$ after the end of infusion, the circulating concentrations of WST11 reached the background level. Evidently, during infusion, small aggregates of WST11 dissociated and bound to albumin (at $\sim 60 \mu M$ WST11 and $\sim 600 \mu M$ BSA, $>90 \%$ of the pigment should become SA-bound, assuming an equilibrium constant of $10^{4} \mathrm{M}^{-1}$ ). Thus, the clearance rate constant after bolus injection probably reflects the pharmacokinetics of small WST11 aggregates, and on infusion, the clearance rate re- 
presents the pharmacokinetics of albumin-bound molecules. At $3 \times$ $\mathrm{t}_{1 / 2}(\sim 21 \mathrm{~min})$, one expects the WST11 to arrive at a steady-state concentration in the plasma. Note that the clearance rates of WST11 from the mouse and rat blood are expected to differ (because of a slower circulation rate, metabolism, etc.) (41).

\section{PDT of melanoma xenografts with WST11}

In light of the pharmacokinetic results described, the VTP protocol was set for $5 \mathrm{~min}$ of illumination starting immediately after the i.v. injection of the pigment. To determine the optimal conditions for the VTP protocol, we varied the drug and light doses over the indicated ranges (Fig. 11). Mice bearing M2R melanoma xenografts were injected i.v. with WST11 (6 or $9 \mathrm{mg} / \mathrm{kg}$ body) and immediately illuminated at increasing light doses $\left(30-45 \mathrm{~J} / \mathrm{cm}^{2}\right)$.

After VTP, all treated tumors developed necrosis within 24-48 h. Tumor flattening was observed for the next 14 days. The best results with $6 \mathrm{mg} / \mathrm{kg}$ WST11 were obtained with a light dose of $45 \mathrm{~J} / \mathrm{cm}^{2}$ (6/10 mice cured and monitored for up to 90 days). At lower light doses (39 and $30 \mathrm{~J} / \mathrm{cm}^{2}$ ), the cure rates declined to $2 / 8$ and $6 / 14$ mice, respectively. Increasing the WST11 dose to $9 \mathrm{mg} / \mathrm{kg}$ at a light dose of $30 \mathrm{~J} / \mathrm{cm}^{2}$ improved the treatment outcome to $70 \%$ cure $(7 / 10$ mice) at 90 days after treatment. The tumor growth rate in the light, dark and untreated controls was similar, and no skin toxicity was observed at $30 \mathrm{~min}$ after i.v. injection (data not shown). These results are similar and even better than those obtained with Tookad ${ }^{\circledR}$ on the same tumor model $(60 \%$ cure, $10 \mathrm{mg} / \mathrm{kg}, 90 \mathrm{~J} / \mathrm{cm}^{2}$ ) (11). Tumor recurrence, if observed, occurred in $\sim 25 \%$ of the treated animals mainly at the tumor rim. A similar phenomenon but to a much higher extent was observed in tumor models treated by antivascular chemotherapy (AVT) reagents and was proposed to reflect accelerated neoangiogenesis at the tumor rim (44). Notably, although tumor regrowth in the AVT was observed with the majority of treated animals, most of the VTP-treated animals were cured and, on increasing the light fluence or the applied drug dose (or both) the cure rate even increased. Furthermore, in other tumor models such as human colon carcinoma, we observed tumor regrowth in only $9 \%$ of the treated animals (A. Scherz and coworkers in preparation). Thus, with respect to local tumor treatment, VTP with WST11 appears to have a clear advantage over treatment with AVT reagents.

\section{CONCLUSIONS}

The results of this study show that WST11 is an effective and safe sensitizer for VTP of relatively large solid tumors. In preliminary experiments, we have demonstrated a shutdown of the tumor vasculature by WST11-VTP already within the course of illumination (O. Mazor, in preparation). The significance of sensitizer binding to SA for conferring VTP warrants additional comments. Such binding may have two effects: (1) because of the long half-life of SA (19 days for humans and 3-4 days for smaller animals such as rabbits) (45), it may significantly extend the drug's lifetime in the circulation and thereby its bioavailability; and (2) complexation with SA should bring the drug to SA target organs such as liver, spleen, kidneys and lungs. Hence, liver and hepatic temporal accumulation and clearance (for smaller molecules) characterize drugs that adsorb to SA (46). The overall clearance of the drug and its biodistribution depend on the affinity to SA relative to tissue and cellular factors in the target organs. Most reported photosensitizers that were found in complexes with SA had a significantly higher affinity to the serum protein than WST11. Such high

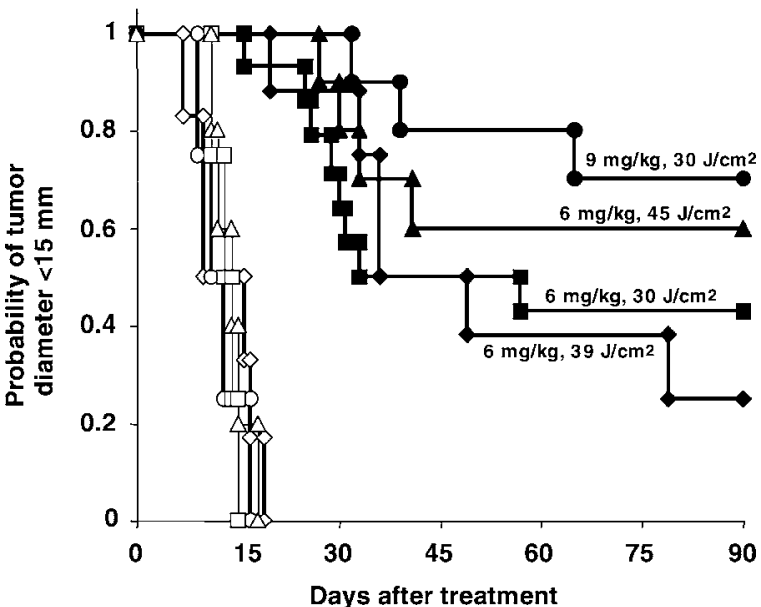

Figure 11. PDT of melanoma xenografts with WST11. Mice bearing M2R melanoma xenografts were i.v. injected with WST11 $(6 \mathrm{mg} / \mathrm{kg})$ and illuminated for $5 \mathrm{~min}$ with a light dose of $30 \mathrm{~J} / \mathrm{cm}^{2}(\mathrm{n}=14$, filled squares), $39 \mathrm{~J} / \mathrm{cm}^{2}\left(\mathrm{n}=8\right.$, filled diamonds) or $45 \mathrm{~J} / \mathrm{cm}^{2}(\mathrm{n}=10$, filled triangles). Mice that were injected with $9 \mathrm{mg} / \mathrm{kg}$ of WST11 were illuminated for 5 min with $30 \mathrm{~J} / \mathrm{cm}^{2}(\mathrm{n}=10$, filled circles). Control groups: untreated $(\mathrm{n}=4$, open squares), the dark control received $6 \mathrm{mg} / \mathrm{kg}(\mathrm{n}=4$, open circles) or $9 \mathrm{mg} / \mathrm{kg}$ $\left(\mathrm{n}=5\right.$, open triangles) of WST11 and the light control, $45 \mathrm{~J} / \mathrm{cm}^{2}(\mathrm{n}=6$, open diamonds).

affinities pose a problem for PDT or VTP because of the prolonged residence in the circulation, and the potential accompanying slow extravasation to surrounding tissues should subject the patient to prolonged skin toxicity. This may account for the 6 weeks of potential toxicity of HPD-treated patients $\left(\sim 3 \cdot t_{1 / 2}\right.$ of SA in humans). Hence, the moderate affinity of WST11 $\left(10^{4} M^{-1}\right)$ is an important advantage because it assures SA-mediated trafficking in the body but allows for rapid dissociation and subsequent clearance in the liver and kidneys as found, for example, for warfarin and other drugs (47).

Taken together, the characteristics of WST11 make it a promising VTP sensitizer for vascular-associated diseases such as cancer and age-related macular degeneration (48).

Acknowledgements-This study is in partial fulfillment of the Ph.D. thesis of O.M. at the Feinberg Graduate School, The Weizmann Institute of Science. Y.S. is the incumbent of the Tillie and Charles Lubin Professorial Chair in Biochemical Endocrinology. A.S. is the incumbent of the Robert and Yaddele Sklare Professorial Chair in Biochemistry. The authors wish to thank Mrs. Ester Shai for her helpful assistance and Dr. P.-H. Brun from Negma-Lerads for continuous fruitful discussions. This study was supported by grants from the Yeda Research and Development Co. Ltd. (Israel) and Steba-Biotech.

\section{REFERENCES}

1. Ackroyd, R., C. Kelty, N. Brown and M. Reed (2001) The history of photodetection and photodynamic therapy. Photochem. Photobiol. 74, 656-669.

2. MacDonald, I. J. and T. J. Dougherty (2001) Basic principles of photodynamic therapy. J. Porphyrins Phtalocyanines 5, 105-129.

3. Handerson, B. W. and T. J. Dougherty (1992) How does photodynamic work? Photochem. Photobiol. 55, 145-157.

4. Kessel, D. and T. J. Dougherty (1999) Agents used in photodynamic therapy. Rev. Contemp. Pharmacother. 10, 19-24.

5. Pandey, R. K., D. A. Bellnier, K. M. Smith and T. J. Dougherty (1991) Chlorin and porphyrin derivatives as potential photosensitizers in photodynamic therapy. Photochem. Photobiol. 53, 65-72.

6. Vakrat, Y., L. Weiner, A. Brandis, O. Mazor, R. Hami, S. Gross, S. Schreiber, Y. Salomon and A. Scherz (1999) Bacteriochlorophyll 
derivatives: phototoxicity, hydrophobicity \& oxygen radicals production. Free Radic. Biol. Med. 27, s129.

7. Noy, D., L. Fiedor, G. Hartwich, H. Scheer and A. Scherz (1998) Metal-substituted bacteriochlorophylls. 2. Changes in redox potentials and electronic transition energies are dominated by intramolecular electrostatic interactions. J. Am. Chem. Soc. 120, 3684-3693.

8. Scherz, A., Y. Salomon, A. Brandis and H. Scheer (2003) Palladiumsubstituted bacteriochlorophyll derivatives and use thereof. US Pat $6,569,846$.

9. Scherz, A., L. Feodor and Y. Salomon (1997) Chlorophyll and bacteriochlorophyll derivatives, their preparation and pharmacological compositions comprising them. US patent 5,650,292.

10. Rosenbach-Belkin, V., L. Chen, L. Fiedor, I. Tregub, F. Pavlotsky, V. Brumfeld, Y. Salomon and A. Scherz (1996) Serine conjugates of chlorophyll and bacteriochlorophyll: phototoxicity in vitro and tissue distribution in mice bearing melanoma. Photochem. Photobiol. 64, 174-181.

11. Gross, S., A. Gilead, A. Scherz, M. Neeman and Y. Salomon (2003) Monitoring photodynamic therapy of solid tumors online by BOLDcontrast MRI. Nat. Med. 9, 1327-1331.

12. Schreiber, S., S. Gross, A. Brandis, A. Harmelin, V. Rosenbach-Belkin, A. Scherz and Y. Salomon (2002) Local photodynamic therapy (PDT) of rat C6 glioma xenografts with Pd-bacteriopheophorbide leads to decreased metastases and increase of animal cure compared with surgery. Int. J. Cancer 99, 279-285.

13. Koudinova, N. V., J. H. Pinthus, A. Brandis, O. Brenner, P. Bendel, J. Ramon, Z. Eshhar, A. Scherz and Y. Salomon (2003) Photodynamic therapy with Pd-bacteriopheophorbide (TOOKAD): successful in vivo treatment of human prostatic small cell carcinoma xenografts. Int. J. Cancer 104, 782-789.

14. Plaks, V., N. Koudinova, U. Nevo, J. H. Pinthus, H. Kanety, Z. Eshhar, J. Ramon, A. Scherz, M. Neeman and Y. Salomon (2004) Photodynamic therapy of established prostatic adenocarcinoma with TOOKAD: a biphasic apparent diffusion coefficient change as potential early MRI response marker. Neoplasia 6, 224-233.

15. Preise, D., O. Mazor, N. Koudinova, M. Liscovitch, A. Scherz and Y. Salomon (2003) Bypass of tumor drug resistance by antivascular therapy. Neoplasia 5, 1-6.

16. Chen, Q., Z. Huang, D. Luck, J. Beckers, P. H. Brun, B. C. Wilson, A. Scherz, Y. Salomon and F. W. Hetzel (2002) Preclinical studies in normal canine prostate of a novel palladium-bacteriopheophorbide (WST09) photosensitizer for photodynamic therapy of prostate cancers. Photochem. Photobiol. 76, 438-445.

17. Kelleher, D. K., O. Thews, A. Scherz, Y. Salomon and P. Vaupel (2004) Perfusion, oxygenation status and growth of experimental tumors upon photodynamic therapy with Pd-bacteriopheophorbide. Int. J. Oncol. 24, 1505-1511.

18. Kelleher, D. K., O. Thews, A. Scherz, Y. Salomon and P. Vaupel (2003) Combined hyperthermia and chlorophyll-based photodynamic therapy: tumour growth and metabolic microenvironment. Br.J.Cancer 89, 2333-2339.

19. Mazor, O. (2004) Synthesis and Phototoxicity of Novel Sulfonated Bacteriochlorophyll Derivatives. Ph.D. thesis, Weizmann Institute of Science, Rehovot, Israel.

20. Gertner, M. R., A. Bogaards, R. A. Weersink, S. A. McCluskey, M. A. Haider, C. K. K. Yue, J. Savard, S. Simpson, P. H. Brun, P. Cohen, A. Scherz, Y. Salomon, A. G. Aprikian, M. M. Elhilali, B. C. Wilson and J. Trachtenberg (2003) Initial results of a 23 phase I/II trial of WST09mediated photodynamic therapy (WST09-PDT) for recurrent prostate cancer following failed external beam radiation therapy (EBRT). In Society of Urologic Oncology, 4th Annual Meeting, Bethesda, Maryland.

21. ten Tije, A. J., J. Verweij, W. J. Loos and A. Sparreboom (2003) Pharmacological effects of formulation vehicles: implications for cancer chemotherapy. Clin. Pharmacokinet. 42, 665-685.

22. Scherz, A., A. Brandis, O. Mazor, Y. Salomon and H. Scheer (2002) Preparation of water soluble anionic bacteriochlorophyll derivatives for use as cancer photodynamic therapy and diagnostic agents. PCT Int. Appl. (2004), 56 pp. WO 2004045492 A2 20040603.

23. Brandis, A., O. Mazor, Y. Salomon and A. Scherz (2003) Analyses of the sensitizer's affinity to serum proteins. 9th Int. Photodyn. Assoc., Book of Abstracts, P-019, p. 43, Miyazaki, Japan, May 20-23.

24. Krammer, B. (2001) Vascular effects of photodynamic therapy. Anticancer Res. 21, 4271-4277.
25. Schnitzer, J. E., P. Oh and D. P. McIntosh (1996) Role of GTP hydrolysis in fission of caveolae directly from plasma membranes. Science 274, 239-242.

26. Tiruppathi, C., W. Song, M. Bergenfeldt, P. Sass and A. B. Malik (1997) Gp60 activation mediates albumin transcytosis in endothelial cells by tyrosine kinase-dependent pathway. J. Biol. Chem. 272, 25968-25975.

27. Bradford, M. M. (1976) A rapid and sensitive method for the quantitation of microgram quantities of protein utilizing the principle of protein-dye binding. Anal. Biochem. 7, 248-254.

28. Zhang, S. Z., M. M. Lipsky, B. F. Trump and I. C. Hsu (1990) Neutral red (NR) assay for cell viability and xenobiotic-induced cytotoxicity in primary cultures of human and rat hepatocytes. Cell Biol. Toxicol. 6, 219-234.

29. Mukherjee, S., R. N. Ghosh and F. R. Maxfield (1997) Endocytosis. Physiol. Rev. 77, 759-803.

30. Cohen, S. and R. Margalit (1990) Binding of porphyrin to human serum albumin. Structure-activity relationships. Biochem. J. 270, 325-330.

31. Sheyhedin, I., K. Aizawa, M. Araake, H. Kumasaka, T. Okunaka and H. Kato (1998) The effect of serum on cellular uptake and phototoxicity of mono-L-aspartyl chlorin $\mathrm{e}_{6}$ (NPe6) in vitro. Photochem. Photobiol. 68, $110-114$.

32. Bohmer, R. M. and G. Morstyn (1985) Uptake of hematoporphyrin derivative by normal and malignant cells: effect of serum, $\mathrm{pH}$, temperature, and cell size. Cancer Res. 45, 5328-5334.

33. Hansen, S. H., K. Sandvig and B. van Deurs (1993) Clathrin and HA2 adaptors: effects of potassium depletion, hypertonic medium, and cytosol acidification. J. Cell Biol. 121, 61-72.

34. Oka, J. A., M. D. Christensen and P. H. Weigel (1989) Hyperosmolarity inhibits galactosyl receptor-mediated but not fluid phase endocytosis in isolated rat hepatocytes. J. Biol. Chem. 264, 12016-12024.

35. Synnes, M., K. Prydz, T. Lovdal, A. Brech and T. Berg (1999) Fluid phase endocytosis and galactosyl receptor-mediated endocytosis employ different early endosomes. Biochim. Biophys. Acta 1421, 317-328.

36. Niles, W. D. and A. B. Malik (1999) Endocytosis and exocytosis events regulate vesicle traffic in endothelial cells. J. Membr. Biol. 167, 85-101.

37. Ball, D. J., S. Mayhew, S. R. Wood, J. Griffiths, D. I. Vernon and S. B. Brown (1999) A comparative study of the cellular uptake and photodynamic efficacy of three novel zinc phthalocyanines of differing charge. Photochem. Photobiol. 69, 390-396.

38. Berg, K. and J. Moan (1997) Lysosomes and microtubules as targets for photochemotherapy of cancer. Photochem. Photobiol. 65, 403-409.

39. Siboni, G., H. Weitman, D. Freeman, Y. Mazur, Z. Malik and B. Ehrenberg (2002) The correlation between hydrophilicity of hypericins and helianthrone: internalization mechanisms, subcellular distribution and photodynamic action in colon carcinoma cells. Photochem. Photobiol. Sci. 1, 483-491.

40. Zilberstein, J., S. Schreiber, M. C. Bloemers, P. Bendel, M. Neeman, E. Schechtman, F. Kohen, A. Scherz and Y. Salomon (2001) Antivascular treatment of solid melanoma tumors with bacteriochlorophyll-serinebased photodynamic therapy. Photochem. Photobiol. 73, 257-266.

41. Shargel, A. and A. B. C. Yu (1999) Applied Biopharmaceutics and Pharmacokinetics. Appleton \& Lange, McGraw-Hill.

42. Huxtable, R. J. (1992) Physiological actions of taurine. Physiol. Rev. 72, 101-163.

43. John, T. A., S. M. Vogel, R. D. Minshall, K. Ridge, C. Tiruppathi and A. B. Malik (2001) Evidence for the role of alveolar epithelial gp60 in active transalveolar albumin transport in the rat lung. J. Physiol. 533, 547-559.

44. Thorpe, P. E. (2004) Vascular targeting agents as cancer therapeutics. Clin. Cancer Res. 10, 415-427.

45. McCurdy, T. R., S. Gataiance, L. J. Eltringham-Smith and W. P. Sheffield (2004) A covalently linked recombinant albumin dimer is more rapidly cleared in vivo than are wild-type and mutant C34A albumin. J. Lab. Clin. Med. 143, 115-124.

46. Takakura, Y., R. I. Mahato and M. Hashida (1998) Extravasation of macromolecules. Adv. Drug Delivery Rev. 34, 93-108.

47. Wosilait, W. D., M. P. Ryan and K. H. Byington (1981) Competition between serum albumin and soluble fraction of liver for binding of warfarin and other drugs. Res. Commun. Chem. Pathol. Pharmacol. 32, 113-121.

48. Behar-Cohen, F. F., M. Berdugo, R. A. Bejjani, F. Valamanesh, M. Savoldelli, L. Jonet, A. Scherz and Y. Salomon (2003) Toxicological evaluation of a new water-soluble photo-sensitizer for PDT, in the rabbit eye. Investig. Ophthalmol. Vis. Sci. 44, E4947. 